\title{
Pengaruh Model Pembelajaran Kooperatif Tipe Teams Games Tournament (TGT) pada Pembelajaran Jarak Jauh terhadap Kemampuan Penalaran Matematis Siswa SMP Negeri 7 Jakarta
}

\author{
Anisatul Hamidah ${ }^{1, \text { a) }}$, Tri Murdiyanto ${ }^{2, \text { b) }}$, Lukman El Hakim³, c) \\ ${ }^{123}$ Universitas Negeri Jakarta, Rawamangun, Jakarta Timur \\ Email: a) anisatulhamidah_1301617006@mhs.unj.ac.id
}

\begin{abstract}
Abstrak
Penelitian ini bertujuan untuk mengetahui apakah terdapat pengaruh model pembelajaran kooperatif tipe Teams Games Tournament (TGT) pada pembelajaran jarak jauh terhadap kemampuan penalaran matematis siswa SMP Negeri 7 Jakarta dan untuk mengetahui besar pengaruh signifikan dari penerapan model pembelajaran kooperatif tipe Teams Games Tournament (TGT) terhadap kemampuan penalaran matematis siswa di SMP Negeri 7 Jakarta. Metode penelitian yang digunakan adalah metode eksperimen semu. Instrumen penelitian yang digunakan adalah instrumen tes kemampuan penalaran matematis berupa 5 soal uraian yang telah dinyatakan valid dan reliabel. Populasi target penelitian adalah seluruh peserta didik SMP Negeri 7 Jakarta. Populasi terjangkau penelitian adalah siswa kelas VII SMP Negeri 7 Jakarta. Teknik pengambilan sampel menggunakan teknik simple random sampling untuk menentukan kelas eksperimen (model pembelajaran kooperatif tipe Teams Games Tournament) dan kelas kontrol (model pembelajaran konvensional). Berdasarkan uji prasyarat analisis data setelah perlakuan, data pada kedua kelas berdistribusi normal dan memiliki varians yang tidak homogen. Pengujian hipotesis statistik uji- $t^{\prime}$ pada taraf signifikansi $\alpha=0,05$, diperoleh $t_{\text {hitung }}=3,041$ lebih tinggi dari nilai kritis $=1,686$, maka $H_{0}$ ditolak dan diperoleh kesimpulan bahwa rata-rata skor tes kemampuan penalaran matematis siswa kelas eksperimen lebih tinggi dari kelas kontrol. Besar pengaruh pada perhitungan Cohen's Effect Size (ES), diperoleh ES = 0,684 dengan percent of Non Overlap sebesar 38,2\% yang dikategorikan medium. Hal ini menunjukkan bahwa terdapat pengaruh signifikan dari penerapan model pembelajaran kooperatif tipe Teams Games Tournament (TGT) pada pembelajaran jarak jauh terhadap kemampuan penalaran matematis siswa SMP Negeri 7 Jakarta.
\end{abstract}

Kata kunci: model pembelajaran teams games tournament, kemampuan penalaran matematis, pembelajaran jarak jauh.

\section{PENDAHULUAN}

Matematika merupakan salah satu bidang pelajaran yang ada di setiap jenjang pendidikan formal di Indonesia. Matematika termasuk ilmu yang sangat krusial untuk diajarkan kepada murid di sekolah. Hal tersebut lantaran matematika memegang peranan sangat banyak dalam mendukung aktivitas dan pekerjaan manusia pada aktivitasnya sehari-hari. Matematika membantu otak manusia bekerja secara rasional. Pada kehidupan sehari-hari, berpikir rasional membantu manusia dalam mengendalikan emosi serta meningkatkan kemampuan berpikir.

Kompetensi kognitif yang harus dicapai oleh siswa dalam domain kompetensi menurut Dewan Riset Nasional adalah berpikir kritis, pemecahan masalah, analisis, penalaran dan argumentasi, interpretasi, pengambilan keputusan, dan pembelajaran adaptif (Winaryati, 2018). Hal ini 
memperlihatkan bahwa kemampuan penalaran memiliki andil dalam tercapainya kompetensi pendidikan abad ke-21. Oleh sebab itu, perlu mengembangkan kemampuan penalaran pada pembelajaran di sekolah.

Kegiatan bernalar mendukung manusia dalam berpikir yang benar, efektif, kategoris, dan runtut untuk memperoleh suatu keabsahan sehingga terhindar dari kekeliruan. Segala aktifitas yang dilakukan manusia pasti akan mempergunakan kemampuan penalaran yang dimilikinya (Ubaidah, 2015). Berdasarkan pengertian penalaran tersebut maka matematika merupakan disiplin pengetahuan yang didapatkan dengan jalan bernalar. Salah satu arah dari adanya belajar matematika ialah agar peserta didik mampu memakai kemampuan penalarannya pada pola dan sifat, mampu memanipulasi matematika untuk menggeneralisasi, serta mampu menyusun bukti dalam menerangkan ide-ide pada pernyataan matematika (Ridwan, 2017).

Pada kenyataannya, yang berjalan di lapangan justru sebaliknya. Kemampuan penalaran anak didik di Indonesia, terutama pada jenjang SMP tidak sesuai dengan apa yang diharapkan. Hal ini terlihat dari rendahnya kemampuan siswa Indonesia di dunia Internasional. Hasil kajian TIMMS dan PISA yang diterbitkan oleh Kementerian Pendidikan dan Kebudayaan memperlihatkan bahwa kemampuan anak didik jenjang SMP khususnya mata pelajaran matematika masih dibawah standar internasional. Bahkan hasil kajian PISA 2012 meletakkan Indonesia di urutan ke-64 dari 65 negara peserta dengan skor rata-rata yang didapatkan adalah 375 , sedangkan skor rata-rata internasional adalah 500 (OECD, 2013).

Sementara itu, dunia saat ini tengah digegerkan dengan suatu virus berbahaya yang pertama kali muncul di Wuhan, Cina. Organisasi kesehatan dunia telah mengumumkan kemunculan wabah ini sebagai pandemik. Pandemik ini membuat pemerintah menganjurkan work from home dan study from home untuk menghindari keramaian dan penyebaran virus berbahaya ini. Kemunculan Coronavirus Disease (Covid-19) yang menjangkit hampir seluruh bagian dunia khususnya Indonesia, sangat berpengaruh terhadap sistem pendidikan di Negara ini. Sistem pendidikan dihadapkan dengan keadaan yang menuntut para guru harus cakap dalam menggunakan media online pada pembelajaran jarak jauh. Pembelajaran jarak jauh menjadi satu-satunya solusi untuk menggantikan pembelajaran secara langsung. Pembelajaran jarak jauh saat ini dilakukan oleh semua pelaksana pendidikan karena diduga menjadikan jalan keluar yang tepat untuk memberikan pengajaran dalam menghadapi wabah Pandemi Covid-19. Oleh karena itu, proses pembelajaran di kelas diganti menjadi pembelajaran jarak jauh. Pada pembelajaran jarak jauh, pendidik dan peserta didik melakukan interaksi secara langsung maupun tidak langsung, interaksi secara langung dapat berupa komunikasi melalui video conference dan interaksi secara tidak langsung misalnya berkirim email untuk mengumpulkan tugas dan hal tersebut tentunya diperlukan koneksi internet (I. Rahmawati, 2016).

Pembelajaran Jarak Jauh (PJJ) yang dilaksanakan saat ini yaitu pembelajaran menggunakan berbagai macam teknologi komunikasi, informasi dan media lainnya dimana siswa terpisah dari guru. Pembelajaran jarak jauh lebih menekankan kemandirian belajar dengan memanfaatkan bahan ajar yang dirancang secara khusus dan disajikan sedemikian rupa yang dapat dipelajari secara mandiri. Pembelajaran jarak jauh menuntut siswa untuk mandiri karena pada pembelajaran ini guru hanya menyuruh dan mengingatkan siswa secara online dan tidak bertemu secara langsung. Siswa memiliki kebebasan untuk dapat belajar tanpa harus hadir di kelas. Seluruh proses belajar mengajar dilakukan di kediaman masing-masing.

Walaupun demikian, terdapat beberapa kesenjangan pembelajaran jarak jauh yang sangat dirasakan oleh siswa dan guru, diantaranya sulitnya siswa memecahkan soal-soal yang ada, sulitnya siswa dalam menemukan informasi mengenai pelajaran. Selain itu, komunikasi yang sulit dengan siswa lainnya dalam pembelajaran membuat siswa tidak dapat mengembangkan kreativitas dan inisiatifnya. Diperlukan model pembelajaran yang mampu mengarahkan siswa untuk beraktivitas belajar secara aktif, kreatif, inovatif dan kolaboratif. Interaksi antara guru dan peserta didik serta antarsesama peserta didik menyebabkan lambatnya proses pembentukan suatu nilai pada kegiatan belajar mengajar. Motivasi yang rendah pada peserta didik dapat membuat peserta didik menjadi gagal dalam menerima pembelajaran. Kesenjangan lainnya dari penerapan pembelajaran jarak jauh diantaranya fokus siswa menjadi terganggu karena adanya aktivitas lain di lingkungannya, siswa dan guru sulit berinteraksi di luar jam pelajaran karena keterbatasan waktu, serta sinyal yang suit pada beberapa tempat 
menyebabkan terhambatnya proses pembelajaran. Pembelajaran jarak jauh juga menyulitkan siswa untuk membagi waktu belajar dan berlatih di rumah, sehingga siswa harus beradaptasi dengan keadaan (Yuangga \& Sunarsi, 2020).

Penelitian yang dilakukan oleh Yuni \& Sylviana Zanthy, dengan subjek penelitian siswa SMP kelas VII yang berjumlah 20 siswa dan instrumen penelitian berupa tes tertulis pada materi segiempat dan segitiga berbentuk uraian yang terdiri dari 5 soal kemampuan penalaran, kemampuan penalaran matematis siswa di SMP tersebut tergolong sangat rendah. Persentase dari semua indikator pada materi segiempat dan segitiga tidak mencapai $50 \%$. Persentase total skor hanya mencapai $48 \%$ pada instrumen yang diuji cobakan. Permasalahan disebabkan banyaknya siswa yang kurang mengerti konsep pada materi segiempat dan segitiga, serta belum dapat mendeskripsikan jawabannya dengan menggunakan bahasa sendiri, banyaknya siswa yang belum dapat mendeskripsikan jawaban dalam bentuk gambar, banyaknya siswa yang kurang mengerti konsep pada materi segiempat dan segitiga, dan tidak bisa membuat model matematika dengan benar sehingga siswa tidak bisa menjelaskan secara matematis (Aprilianti \& Zanthy, 2018).

Kemampuan penalaran matematis terkait pembelajaran yang dilakukan harus mendapatkan atensi dari berbagai pihak khususnya pengajar matematika. Salah satu faktor yang membuat kemampuan penalaran matematis rendah ialah pembelajaran yang banyak didominasi oleh guru. Oleh karena itu, dibutuhkan suatu model pembelajaran yang lebih berfokus kepada kegiatan peserta didik (Mahmuzah \& Aklimawati, 2017).

Model pembelajaran memegang kedudukan penting dalam upaya meningkatkan keberhasilan kegiatan pembelajaran. Salah satu model pembelajaran yang bisa digunakan adalah model pembelajaran kooperatif tipe Teams Games Tournament (TGT), yaitu model pembelajaran yang melibatkan siswa yang lebih pandai sebagai tutor sebaya serta berisi unsur permainan. Kegiatan belajar mengajar pada model pembelajaran kooperatif tipe TGT bertujuan agar siswa belajar lebih santai serta mengembangkan rasa tanggung jawab, bersaing secara sehat dan membuat siswa lebih terlibat dalam belajar (Supriatin et al., 2015).

Langkah mengoptimalkan penalaran matematis siswa ialah dengan memanfaatkan model pembelajaran yang lebih menekankan peran aktif dan semangat siswa dalam setiap kegiatan belajar. Salah satu model pembelajaran yang tepat untuk membuat siswa berperan aktif dan bersemangat yaitu model pembelajaran kooperatif, lantaran model tersebut memiliki elemen yang menuntut siswa harus bekerjasama, diskusi serta presentasi secara berkelompok. Model pembelajaran kooperatif tipe Teams Games Tournament (TGT) diduga dapat menjadikan siswa termotivasi dalam meningkatkan kemampuan penalaran matematisnya, sebab model tersebut memiliki elemen utama yakni presentasi kelas, tim, game, turnamen, dan rekognisi tim sehingga menuntut siswa untuk bekerja dalam kelompok kecil (Ainun, 2015).

Hasil beberapa peneliti yang melakukan penelitian dengan model pembelajaran kooperatif tipe Teams Games Tournament, hasil keseluruhan menunjukkan adanya peningkatan kemampuan penalaran matematis siswa yang memperoleh pembelajaran model pembelajaran kooperatif tipe Teams Games Tournament (TGT) lebih baik dari siswa yang memperoleh pembelajaran dengan pendekatan konvensional. Namun, penelitian-penelitian tersebut dilakukan dengan pembelajaran secara langsung di kelas. Oleh karena itu, peneliti ingin mengetahui bagaimana jika model pembelajaran kooperatif tipe Teams Games Tournament dilakukan tidak langsung, dengan kata lain, penelitian dilakukan melalui pembelajaran jarak jauh melalui berbagai media pembelajaran non-tatap muka dibantu dengan platform Whatsapp Groutp dan Google Classroom. Pembelajaran dilakukan dengan tiga langkah utama yaitu pembentukan tim, permainan, dan pertandingan yang akan dilakukan melalui Whasapp Group. Pertandingan dilakukan secara tim dan setiap tim diberikan waktu untuk menjawab soal secara spontan yang diberikan guru. Belum ada penelitian yang membahas hubungan antara model pembelajaran kooperatif tipe Teams Games Tournament (TGT) yang dilakukan pada pembelajaran jarak jauh dengan kemampuan penalaran matematis siswa. Oleh karena itu, dilaksanakannya pembelajaran kooperatif tipe Teams Games Tournament (TGT) menjadi kebaruan dalam peneliatian dan menunjukkan pentingnya penelitian yang akan dilakukan. Berdasarkan uraian di atas, penelitian yang akan dilakukan berjudul "Pengaruh Model Pembelajaran Kooperatif Tipe Teams Games Tournament (TGT) pada Pembelajaran Jarak Jauh terhadap Kemampuan Penalaran Matematis Siswa SMP Negeri 7 Jakarta". 
Dengan adanya penelitian ini, diharapkan dapat menambah wawasan tentang teori pembelajaran matematika berkaitan dengan pemilihan model pembelajaran yang sesuai. Harapan lainnya adalah agar dapat memberikan sumbangan ilmu dalam penggunaan pembelajaran online pada pembelajaran matematika di sekolah. Selain itu, hasil penelitian ini juga diharapkan dapat membantu para pendidik untuk mengoptimalkan proses pembelajaran jarak jauh untuk siswanya.

\section{METODE}

Penelitian ini merupakan penelitian kuantitatif dengan metode penelitian yang digunakan adalah metode eksperimen semu (Quasi Experiment). Populasi target penelitian adalah seluruh peserta didik SMP Negeri 7 Jakarta. Populasi terjangkau penelitian adalah siswa kelas VII SMP Negeri 7 Jakarta. Populasi terjangkau dipilih dengan teknik Cluster Random Sampling dan teknik pengambilan sampel menggunakan teknik Simple Random Sampling. Sampel dipilih dua dari delapan kelas berdasarkan kelompok kelas yang berdistribusi normal dan memiliki varians yang relatif homogen dan memiliki kesamaan rata-rata pada kondisi awal kelas. Satu kelas sebagai kelas eksperimen dengan 40 siswa (VIIG) yang mendapat perlakuan model pembelajaran kooperatif tipe TGT dan satu kelas sebagai kelas kontrol dengan 39 siswa (VII-H) yang diajarkan menggunakan model pembelajaran konvensional, dan keduanya akan belajar secara jarak jauh.

Instrumen penelitian yang digunakan adalah instrumen tes kemampuan penalaran matematis pada pokok bahasan perbandingan. Tes ini berupa lima soal uraian yang telah diuji validitas dan reliabilitasnya. Berikut contoh soal yang digunakan dalam penelitian:

TABEL 1. Soal Instrumen Tes Kemampuan Penalaran Matematis

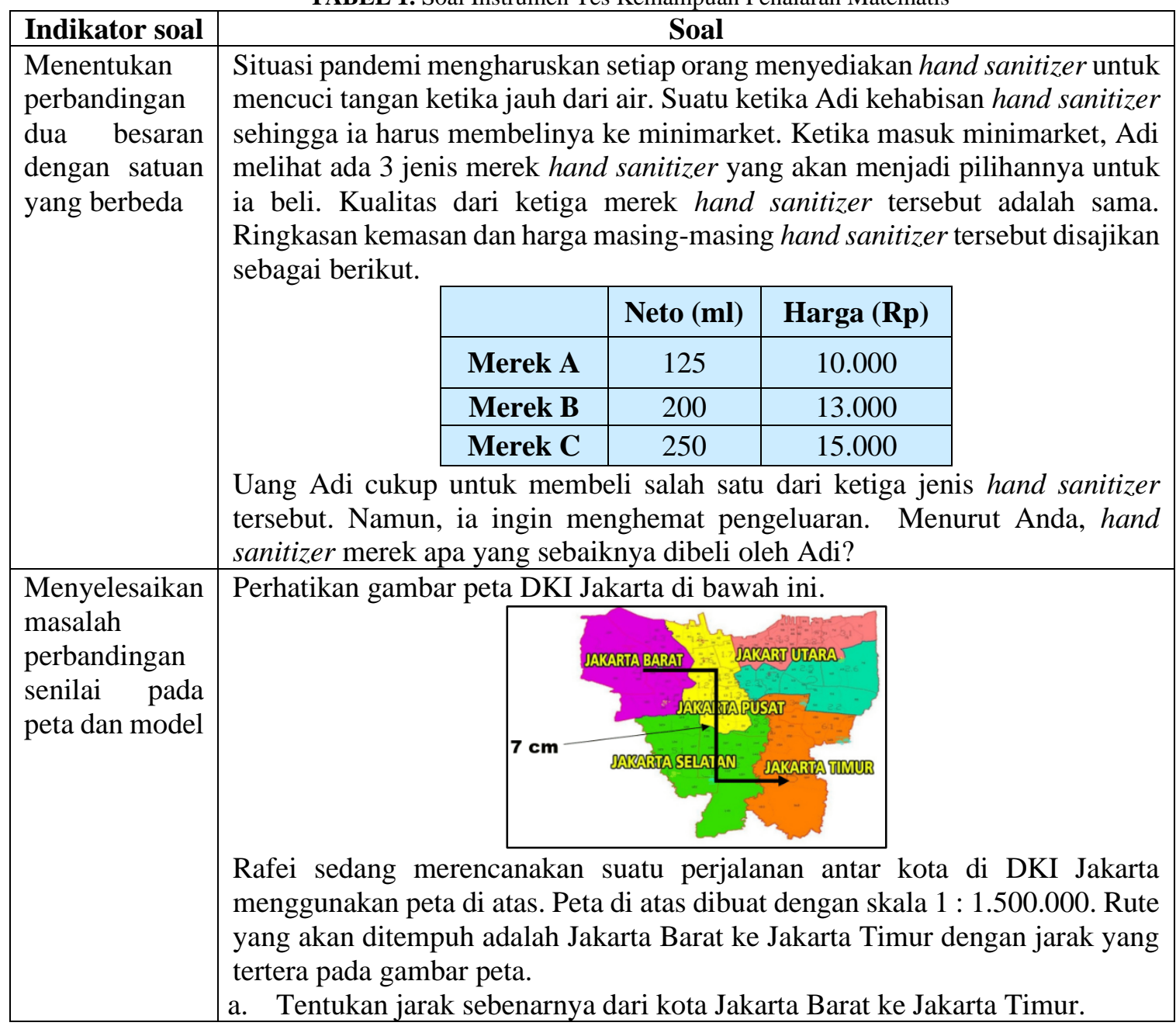


b. Apabila Rafei berangkat dari Jakarta Barat pukul 06.00 WIB menggunakan mobil dengan kecepatan rata-rata $70 \mathrm{~km} / \mathrm{jam}$, pukul berapa ia tiba di Jakarta Timur?

Hasil uji validitas instrumen tes dapat dilihat pada Tabel 2 berikut:

TABEL 2. Hasil Uji Validitas Instrumen Tes

\begin{tabular}{|c|c|c|c|c|}
\hline $\begin{array}{c}\text { Butir } \\
\text { Soal }\end{array}$ & $\sum_{\boldsymbol{i}}^{\boldsymbol{n}}\left(\boldsymbol{r}_{\boldsymbol{i}}-\boldsymbol{l}_{\mathbf{0}}\right)$ & {$[\boldsymbol{n}(\boldsymbol{c}-\mathbf{1})]$} & $\boldsymbol{V}$ & $\begin{array}{c}\text { Keterangan Butir } \\
\text { Soal }\end{array}$ \\
\hline $\boldsymbol{x}_{\mathbf{1}}$ & 129 & 144 & $V_{1}=\frac{129}{144}=0,896$ & Memadai \\
\hline $\boldsymbol{x}_{\mathbf{2}}$ & 133 & 144 & $V_{2}=\frac{133}{144}=0,924$ & Memadai \\
\hline $\boldsymbol{x}_{\mathbf{3}}$ & 105 & 144 & $V_{3}=\frac{105}{144}=0,729$ & Memadai \\
\hline $\boldsymbol{x}_{\mathbf{4}}$ & 120 & 144 & $V_{4}=\frac{120}{144}=0,834$ & Memadai \\
\hline $\boldsymbol{x}_{\mathbf{5}}$ & 89 & 144 & $V_{5}=\frac{89}{144}=0,618$ & Memadai \\
\hline
\end{tabular}

Hasil perhitungan reliabilitas tes kemampuan penalaran matematis yang terdiri dari lima butir soal, diperoleh koefisien reliabilitas instrumen $\left(r_{11}\right)$ sebesar 0,723 , hal ini menunjukkan bahwa $0,70 \leq r_{11}<$ 0,90 sehingga instrumen penelitian dapat dikatakan reliabel dengan kategori tinggi. Teknik analisis data setelah perlakuan dihitung menggunakan uji- $t^{\prime}$ untuk dua sampel independen dengan dilakukan uji normalitas dan uji homogenitas terlebih dahulu. Selanjutnya dilakukan perhitungan Effect Size menggunakan rumus Cohen's effect size (ES) untuk mengetahui besar pengaruh model pembelajaran kooperatif tipe Teams Games Tournament (TGT) pada pembelajaran jarak jauh terhadap kemampuan penalaran matematis siswa SMP Negeri 7 Jakarta.

\section{HASIL DAN PEMBAHASAN}

\section{Uji Prasyarat Analisis Data Sebelum Perlakuan}

Hasil uji normalitas sebelum perlakuan disajikan dalam Tabel 3.

TABEL 3. Hasil Uji Normalitas Sebelum Perlakuan

\begin{tabular}{|c|c|c|c|c|c|}
\hline Kelas & $\mathbf{N}$ & $\boldsymbol{L}_{\mathbf{0}}$ & $\boldsymbol{L}_{\text {tabel }}$ & Keterangan & Keputusan \\
\hline VII-A & 39 & 0,097 & 0,142 & $L_{0}<L_{\text {tabel }}$ & Terima $H_{0}$ \\
\hline VII-B & 38 & 0,062 & 0,144 & $L_{0}<L_{\text {tabel }}$ & Terima $H_{0}$ \\
\hline VII-C & 40 & 0,158 & 0,140 & $L_{0}>L_{\text {tabel }}$ & Tolak $H_{0}$ \\
\hline VII-D & 40 & 0,099 & 0,140 & $L_{0}<L_{\text {tabel }}$ & Terima $H_{0}$ \\
\hline VII-E & 38 & 0,051 & 0,144 & $L_{0}<L_{\text {tabel }}$ & Terima $H_{0}$ \\
\hline VII-F & 40 & 0,123 & 0,140 & $L_{0}<L_{\text {tabel }}$ & Terima $H_{0}$ \\
\hline VII-G & 40 & 0,107 & 0,140 & $L_{0}<L_{\text {tabel }}$ & Terima $H_{0}$ \\
\hline VII-H & 39 & 0,116 & 0,142 & $L_{0}<L_{\text {tabel }}$ & Terima $H_{0}$ \\
\hline
\end{tabular}

Berdasarkan Tabel 3, dapat dilihat bahwa hanya kelas VII-C yang memiliki nilai $L_{0}>L_{\text {tabel }}$ sehingga tolak $H_{0}$ atau data tidak berdistibusi normal. Sehingga dapat diambil kesimpulan bahwa kelas VII-A, VII-B, VII-D, VII-E, VII-F, VII-G, dan VII-H adalah berdistribusi normal.

Hasil uji homogenitas sebelum perlakuan disajikan dalam Tabel 4. 
TABEL 4. Hasil Uji Homogenitas Sebelum Perlakuan

\begin{tabular}{|c|c|c|c|}
\hline $\boldsymbol{x}_{\text {hitung }}^{2}$ & $\boldsymbol{x}_{\left(\frac{\boldsymbol{\alpha}}{\mathbf{2}}, \boldsymbol{k}-\mathbf{1}\right)}^{2}$ & $\boldsymbol{x}_{\left(\mathbf{1}-\frac{\boldsymbol{\alpha}}{\mathbf{2}}, \boldsymbol{k}-\mathbf{1}\right)}^{\mathbf{2}}$ & Interpretasi \\
\hline 2,371 & 1,237 & 14,449 & Memiliki varians yang relatif homogen \\
\hline
\end{tabular}

Berdasarkan Tabel 4, diketahui bahwa $x_{\left(\frac{\alpha}{2}, k-1\right)}^{2}=1,237<x_{\text {hitung }}^{2}=2,371<x_{\left(1-\frac{\alpha}{2}, k-1\right)}^{2}=$ 14,449 , artinya keputusan terima $H_{0}$. Maka dapat diambil kesimpulan bahwa ketujuh kelas yang telah diuji memiliki varians yang relatif homogen.

Hasil uji kesamaan rata-rata disajikan dalam Tabel 5.

TABEL 5. Hasil Uji Kesamaan Rata-rata

\begin{tabular}{|c|c|c|c|}
\hline $\boldsymbol{F}_{\text {hitung }}$ & $\boldsymbol{F}_{\left(\mathbf{1}-\frac{\boldsymbol{\alpha}}{2}, \boldsymbol{d} \boldsymbol{k}_{\boldsymbol{A}}, \boldsymbol{d} \boldsymbol{k}_{\boldsymbol{D}}\right)}$ & $\boldsymbol{F}_{\left(\frac{\boldsymbol{\alpha}}{2}, \boldsymbol{d} \boldsymbol{k}_{\boldsymbol{A}}, \boldsymbol{d} \boldsymbol{k}_{\boldsymbol{D}}\right)}$ & Interpretasi \\
\hline 0,798 & 0,205 & 2,456 & Rata-rata sama \\
\hline
\end{tabular}

Berdasarkan Tabel 5, diketahui bahwa nilai $F_{\left(1-\frac{\alpha}{2}, d k_{A}, d k_{D}\right)}=0,205<F_{\text {hitung }}=0,798<$ $F_{\left(\frac{\alpha}{2}, d k_{A}, d k_{D}\right)}=2,456$, artinya keputusan $H_{0}$ diterima. Hal ini memberikan kesimpulan bahwa ketujuh kelas yaitu VII-A, VII-B, VII-D, VII-E, VII-F, VII-G, dan VII-H memiliki kesamaan rata-rata. Kemudian, dari ketujuh kelas tersebut dipilih kelas VII-G sebagai kelas eksperimen, yaitu kelas yang memperoleh perlakuan berupa model pembelajaran kooperatif tipe Teams Games Tournament (TGT) dan kelas VII-H sebagai kelas kontrol, yaitu kelas yang memperoleh perlakuan berupa model pembelajaran konvensional yang keduanya dilakukan pada pembelajaran jarak jauh.

\section{Uji Prasyarat Analisis Data Setelah Perlakuan}

Hasil uji normalitas setelah perlakuan disajikan dalam Tabel 6.

TABEL 6. Hasil Uji Normalitas Setelah Perlakuan

\begin{tabular}{|c|c|c|c|c|}
\hline Kelas & $\boldsymbol{L}_{\mathbf{0}}$ & $\boldsymbol{L}_{\text {tabel }}$ & Keterangan & Kesimpulan \\
\hline Eksperimen & 0,064 & 0,14 & $L_{0}<L_{\text {tabel }}$ & Terima $H_{0}$ \\
\hline Kontrol & 0,113 & 0,142 & $L_{0}<L_{\text {tabel }}$ & Terima $H_{0}$ \\
\hline
\end{tabular}

Berdasarkan Tabel 6, diketahui bahwa kedua kelas yang diuji memiliki nilai $L_{0}<L_{\text {tabel }}$, artinya keputusan terima $H_{0}$. Hal ini memberikan kesimpulan bahwa kedua kelas yaitu VII-G dan VII-H berdistribusi normal.

Hasil uji homogenitas setelah perlakuan disajikan dalam Tabel 7.

TABEL7. Hasil Uji Homogenitas Setelah Perlakuan

\begin{tabular}{|c|c|c|c|}
\hline $\boldsymbol{F}_{\text {hitung }}$ & $\boldsymbol{F}_{\left(\mathbf{1}-\frac{\mathbf{1}}{\mathbf{2}} \boldsymbol{\alpha}\right)\left(\boldsymbol{n}_{\mathbf{1}}-\mathbf{1}, \boldsymbol{n}_{\mathbf{2}}-\mathbf{1}\right)}$ & $\boldsymbol{F}_{\left(\frac{\mathbf{1}}{\mathbf{2}} \boldsymbol{\alpha}\right)\left(\boldsymbol{n}_{\mathbf{1}}-\mathbf{1}, \boldsymbol{n}_{\mathbf{2}}-\mathbf{1}\right)}$ & Interpretasi \\
\hline 3,160 & 0,527 & 1,901 & Tidak homogen \\
\hline
\end{tabular}

Berdasarkan Tabel 7, diketahui bahwa $F_{\text {hitung }}=3,160>F_{\left(\frac{1}{2} \alpha\right)\left(n_{1}-1, n_{2}-1\right)}=1,901$, maka dapat diambil kesimpulan bahwa tolak $H_{0}$ yang artinya hasil tes kemampuan penalaran matematis kelas eksperimen dan kelas kontrol memiliki varians yang tidak homogen dengan taraf signifikansi $\alpha=0,05$ 


\section{Uji Analisis Data}

Hasil uji hipotesis disajikan dalam Tabel 8.

TABEL 8. Hasil Uji-t' Dua Sampel Penelitian

\begin{tabular}{|c|c|c|}
\hline Nilai $\boldsymbol{t}^{\prime}$ & Nilai $\frac{\boldsymbol{w}_{\mathbf{1}} \boldsymbol{t}_{\mathbf{1}}+\boldsymbol{w}_{\mathbf{2}} \boldsymbol{t}_{\mathbf{2}}}{\boldsymbol{w}_{\mathbf{1}}+\boldsymbol{w}_{2}}$ & Kesimpulan \\
\hline 3,041 & 1,686 & Tolak $H_{0}$ \\
\hline
\end{tabular}

Berdasarkan Tabel 8, diketahui bahwa nilai $t^{\prime} \geq \frac{w_{1} t_{1}+w_{2} t_{2}}{w_{1}+w_{2}}$, artinya keputusan tolak $H_{0}$. Hal ini memberikan kesimpulan bahwa rata-rata hasil tes kemampuan penalaran matematis siswa kelas eksperimen lebih tinggi daripada rata-rata hasil tes kemampuan penalaran siswa kelas kontrol pada taraf signifikansi $\alpha=0,05$.

\section{Uji Besar Pengaruh}

Hasil uji besar pengaruh disajikan dalam Tabel 9.

TABEL 9. Hasil Uji Besar Pengaruh

\begin{tabular}{|c|c|c|}
\hline ES & Kategori & Persentase \\
\hline 0,684 & Medium & $38,2 \%$ \\
\hline
\end{tabular}

Berdasarkan Tabel 9, dapat disimpulkan bahwa besar pengaruh penerapan model pembelajaran kooperatif tipe Teams Games Tournament (TGT) terhadap kemampuan penalaran matematis siswa pada pembelajaran jarak jauh berada pada kategori medium dengan percent of Non Overlap sebesar $38,2 \%$.

Berdasarkan hasil pengujian hipotesis, diperoleh bahwa rata-rata hasil tes kemampuan penalaran matematis siswa kelas eksperimen yang menggunakan model pembelajaran kooperatif tipe Teams Games Tournament (TGT) lebih tinggi dari rata-rata hasil tes kemampuan penalaran matematis siswa kelas kontrol yang mendapatkan model pembelajaran konvensional. Berdasarkan hal tersebut dapat disimpulkan bahwa model pembelajaran kooperatif tipe Teams Games Tournament (TGT) memberi pengaruh positif dalam mengembangkan kemampuan penalaran matematis siswa dibandingkan dengan model pembelajaran konvensional.

Perbedaan hasil yang diberikan oleh kedua kelas dapat terjadi karena perlakuan yang diberikan kepada kedua kelas berbeda. Kelas eksperimen diberikan pembelajaran dengan model pembelajaran kooperatif tipe Teams Games Tournament (TGT) yang menekankan kerjasama kelompok dan penggunaan turnamen antar tim dengan menggunakan permainan-permainan akademik yang didalamnya terdiri dari serangkaian pembelajaran kelompok (teams), permainan (game), dan pertandingan (tournament) antar kelompok sehingga pembelajaran akan berjalan lebih menyenangkan.

Sesuai dengan hasil penelitian yang dilakukan oleh Yanti Purnamasari dalam jurnalnya yang berjudul "Pengaruh Model Pembelajaran Kooperatif Tipe Teams Games Tournament (TGT) terhadap Kemandirian Belajar dan Peningkatan Kemampuan Penalaran dan Koneksi Matematik Peserta Didik SMPN 1 Kota Tasikmalaya" bahwa peningkatan kemampuan penalaran matematis peserta didik yang mengikuti pembelajaran kooperatif tipe Teams Games Tournament (TGT) lebih baik daripada siswa yang mengikuti pembelajaran langsung, dikarenakan pembelajaran kooperatif tipe Teams Games Tournament (TGT) lebih memberi kesempatan kepada siswa untuk aktif dan terlibat secara langsung dalam aktivitas matematis (Purnamasari, 2014).

Penelitian lain yang menunjukkan kemampuan penalaran matematis siswa meningkat setelah diterapkan model pembelajaran kooperatif tipe Teams Games Tournament ialah penelitian yang dilakukan oleh Nur Ainun pada artikelnya yang berjudul "Peningkatan Kemampuan Penalaran Matematis Siswa Madrasah Aliyah Melalui Model Pembelajaran Kooperatif Tipe Teams Games Tournament". Secara keseluruhan peningkatan kemampuan penalaran matematis siswa yang memperoleh pembelajaran dengan model pembelajaran kooperatif tipe Teams Games Tournament 
lebih baik dari siswa yang memperoleh pembelajaran dengan pendekatan konvensional dikarenakan langkah pada model Teams Games Tournament (TGT) membuat siswa merasa terlibat secara langsung dalam pembelajaran sehingga penalaran matematisnya terasah dengan baik (Ainun, 2015).

Sesuai pula dengan hasil penelitian Nurina Kurniasari Rahmawati pada artikelnya dengan judul "Implementasi Teams Games Tournaments dan Number Head Together ditinjau dari Kemampuan Penalaran Matematis" yang memperoleh hasil bahwasanya prestasi matematika dengan model TGT lebih baik dibandingkan prestasi matematika dengan model pembelajaran NHT dan pembelajaran Konvensional; dan siswa dengan kemampuan penalaran matematis tinggi memiliki prestasi belajar yang lebih baik dibandingkan dengan kemampuan penalaran matematis sedang dan rendah $(\mathrm{N}$. K. Rahmawati, 2017).

Model pembelajaran kooperatif tipe Teams Games Tournament (TGT) diawali dengan guru memberikan informasi tentang materi yang akan dipelajari kemudian guru menjelaskan materi yang dipelajari pada hari tersebut berbantuan media Power Point (PPT) melalui ketikan atau rekaman suara di Whatsapp Group.

Model pembelajaran kooperatif tipe Teams Games Tournament (TGT) memiliki langkah yang bertahap yaitu presentasi materi, pembentukan kelompok, dan permainan pertandingan. Langkah tersebut mendukung setiap indikator penalaran matematis dan diharapkan dapat membantu guru dalam mengefektifkan kemampuan bernalar siswa, sehingga model ini bisa mengatasi kesulitan pada pembelajaran. Siswa diminta untuk berdiskusi berkaitan dengan LKPD yang diberikan oleh guru. Ketika siswa mengalami kesulitan mengerjakan LKPD, siswa diberi kesempatan untuk bertanya kepada guru. Siswa diberi waktu untuk berdiskusi dan bekerja bersama kelompoknya kemudian tugas LKPD dikumpulkan oleh perwakilan kelompok melalui Google Classroom. Turnamen antar kelompok dilakukan setiap dua materi pada subbab perbandingan selesai diajarkan. Pada kegiatan turnamen, pertama-tama guru meminta ketua kelompok untuk mengecek kehadiran anggotanya dan meminta setiap kelompok untuk mempersiapkan alat tulis, kemudian guru menjelaskan aturan tertentu yang harus dipatuhi selama pertandingan. Guru menyiapkan kartu soal sebanyak 16 yang isinya merupakan pertanyaan yang akan dijawab oleh siswa. Guru memberikan kesempatan kepada setiap kelompok untuk memilih angka dari 1-8 lalu memberikan pertanyaan kepada kelompok yang bersangkutan. Pertanyaan diberikan dalam bentuk lisan ataupun tulisan yang ditampilkan pada Whatsapp Group. Jika semua kelompok sudah mendapat giliran, kembali lagi setiap kelompok diberi kesempatan untuk memilih angka 9-16 dan memberikan pertanyaan sesuai dengan angka yang dipilih oleh kelompok. Setiap kelompok yang menjawab harus menjelaskan jawabannya di depan teman-temannya, selanjutnya guru akan melanjutkan ke kelompok berikutnya apabila jawaban benar, dan soal akan dijawab oleh kelompok berikutnya apabila jawaban salah. Saat pertandingan dilaksanakan, setiap kelompok diperbolehkan diskusi pada grupnya masing-masing mengenai soal yang sedang diberikan dan guru dapat memantau proses diskusi setiap kelompok pada grup kelompoknya masing-masing sehingga dapat memacu keaktifan siswa di setiap kelompok. Selanjutnya guru menghitung perolehan skor setiap kelompok kemudian skor tersebut disampaikan pada akhir turnamen.

Pada akhir pembelajaran, guru memberikan umpan balik positif dan penguatan maupun penghargaan terhadap keberhasilan siswa dan memberikan motivasi kepada siswa yang kurang atau belum berpartisipasi aktif. Selanjutnya guru mengarahkan siswa secara bersama-sama untuk membuat kesimpulan dari materi yang telah dibahas dan memberikan informasi mengenai materi pada pertemuan berikutnya. Peran guru dalam model pembelajaran kooperatif tipe Teams Games Tournament (TGT) adalah sebagai fasilitator untuk membantu siswa dalam memahami materi pelajaran dan fasilitator dalam pertandingan (Tournament).

Pada kelas kontrol, pembelajaran yang diterapkan tentunya berbeda. Kelas kontrol belajar menggunakan model pembelajaran konvensional yang biasa diterapkan di SMP Negeri 7 Jakarta yaitu model pembelajaran ekspositori. Model pembelajaran ini menekankan proses penyampaian materi secara verbal dari guru kepada sekelompok siswa dan pembelajaran terpusat pada guru sebagai sumber informasi. Kemudian guru memberi contoh soal dan siswa diminta untuk mengerjakan soal yang diberikan. Selanjutnya siswa diberikan tugas untuk dikumpulkan pada pertemuan yang akan datang. Peran guru sangat dominan membuat pembelajaran menjadi kurang menyenangkan dan membuat siswa pasif dalam kegiatan belajar mengajar. 
Penelitian yang telah dilakukan pada kelas eksperimen yang mendapatkan pembelajaran dengan model pembelajaran kooperatif tipe Teams Games Tournament (TGT) memiliki beberapa kendala. Diantaranya, proses pembelajaran dalam pembelajaran jarak jauh membutuhkan kontrol diri yang tinggi dari gangguan eksternal, kekuatan jaringan internet yang kurang merata membuat beberapa siswa terkendala dalam menjawab pertanyaan saat turnamen, sulitnya guru dalam menguasai kelas saat kegiatan turnamen, serta kurangnya waktu dalam mengerjakan LKPD sehingga proses pengerjaan LKPD dilaksanakan secara asinkron.

\section{PENUTUP}

Berdasarkan hasil pengujian hipotesis pada taraf signifikan $\alpha=0,05$, hasil t hitung menunjukkan $t^{\prime}=3,041 \geq \frac{w_{1} t_{1}+w_{2} t_{2}}{w_{1}+w_{2}}=1,686$ yang berarti tolak $H_{0}$. Hal ini menunjukkan bahwa kemampuan penalaran matematis siswa pada pembelajaran jarak jauh yang diajarkan dengan model pembelajaran kooperatif tipe Teams Games Tournament (TGT) lebih tinggi daripada siswa yang diajarkan menggunakan model pembelajaran konvensional. Oleh karena itu, dari hasil penelitian ini dapat diambil kesimpulan bahwa terdapat pengaruh signifikan model pembelajaran kooperatif tipe Teams Games Tournament (TGT) pada pembelajaran jarak jauh terhadap kemampuan penalaran matematis siswa di SMP Negeri 7 Jakarta. Besar pengaruh model pembelajaran kooperatif tipe Teams Games Tournament (TGT) pada pembelajaran jarak jauh terhadap kemampuan penalaran matematis siswa di SMP Negeri 7 Jakarta adalah sebesar 0,684 dengan percent of Non Overlap sebesar 38,2\% atau berada pada kategori medium.

Peneliti menemukan beberapa kendala saat melakukan penelitian di kelas eksperimen. Diantaranya, proses pembelajaran dalam pembelajaran jarak jauh memerlukan kontrol diri yang tinggi terhadap gangguan dari luar, kekuatan jaringan internet yang kurang merata membuat beberapa siswa terkendala dalam menjawab pertanyaan saat turnamen, sulitnya guru dalam menguasai kelas saat kegiatan turnamen, serta kurangnya waktu dalam mengerjakan LKPD sehingga proses pengerjaan LKPD dilaksanakan secara asinkron.

Untuk penelitian lebih lanjut, diharapkan dapat dilengkapi dengan meneliti kemampuan yang lain namun menggunakan model yang sama. Selain itu, perlu adanya penelitian lebih lanjut mengenai model pembelajaran kooperatif tipe Teams Games Tournament (TGT) terhadap kemampuan penalaran matematis siswa pada pokok bahasan lainnya. Peneliti juga diharapkan dapat meneliti di sekolah dan tingkatan yang berbeda dan menggunakan waktu yang lebih lama.

\section{REFERENSI}

Ainun, N. (2015). Peningkatan kemampuan penalaran matematis siswa madrasah aliyah melalui model pembelajaran kooperatif tipe teams games tournament. Jurnal Peluang, 4(1), 55-63. http://jurnal.unsyiah.ac.id/peluang/article/view/5859

Aprilianti, Y., \& Zanthy, L. S. (2018). Analisis kemampuan penalaran siswa SMP pada materi segiempat dan segitiga. Journal on Education, 1(2), 524-532. https://doi.org/10.22460/jpmi.v1i5.p1025-1036

Mahmuzah, R., \& Aklimawati. (2017). Peningkatan kemampuan penalaran matematis siswa SMP $\begin{array}{lllll}\text { melalui pendekatan problem } & \text { 71-80. }\end{array}$ http://numeracy.stkipgetsempena.ac.id/home/article/viewFile/54/49

OECD. (2013). Indonesia students performance (PISA 2012). http://gpseducation.oecd.org

Purnamasari, Y. (2014). Pengaruh model pembelajaran kooperatif tipe teams games tournament (Tgt) terhadap kemandirian belajar dan peningkatan kemampuan penalaran dan koneksi matematik peserta didik SMPN 1 kota tasikmalaya. Jurnal Pendidikan Dan Keguruan, 1(1). https://www.neliti.com/publications/209664/pengaruh-model-pembelajaran-kooperatif-tipe- 
teams-games-tournament-tgt-terhadap

Rahmawati, I. (2016). Pelatihan dan pengembangan pendidikan jarak jauh berbasis digital class platform edmodo (I. (2016). P. dan pengembangan pendidikan jarak jauh berbasis digital class platform edmodo. Rahmawati (ed.)). Universitas Terbuka Convention Center. http://repository.ut.ac.id/6536/

Rahmawati, N. K. (2017). Implementasi Teams Games Tournaments dan Number Head Together ditinjau dari Kemampuan Penalaran Matematis. Al-Jabar : Jurnal Pendidikan Matematika, 8(2), 121-134. https://doi.org/10.24042/ajpm.v8i2.1585

Ridwan, M. (2017). Profil Kemampuan Penalaran Matematis Siswa Ditinjau Dari Gaya Belajar. KALAMATIKA Jurnal Pendidikan Matematika, 2(2Ridwan, M. (2017). Profil Kemampuan Penalaran Matematis Siswa Ditinjau Dari Gaya Belajar. KALAMATIKA Jurnal Pendidikan Matematika, 2(2), 193-206. https://doi.org/10.22236/kalamatika.vol2no2.2017pp193-206), 193206. http://kalamatika.matematika-uhamka.com/index.php/kmk/article/view/88

Supriatin, S., Caswita, C., \& ... (2015). Efektivitas model pembelajaran kooperatif tipe TGT terhadap pemahaman konsep matematis siswa. Jurnal Pendidikan ..., 3(5). http://jurnal.fkip.unila.ac.id/index.php/MTK/article/view/9553

Ubaidah, N. (2015). Meningkatkan kemampuan penalaran siswa melalui pembelajaran auditory intellectual repetition berbantuan buku siswa pada materi persamaan trigonometri. Fibonacci Jurnal Pendidikan Matematika Dan Matematika, 3(1), 11-22. https://jurnal.umj.ac.id/index.php/fbc/article/download/1725/1756

Winaryati, E. (2018). Penilaian kompetensi siswa abad 21. Prosiding Seminar Nasional \& Internasional, 1(1), 6-19. https://jurnal.unimus.ac.id/index.php/psn12012010/article/view/4070

Yuangga, K. D., \& Sunarsi, D. (2020). Pengembangan media dan strategi pembelajaran untuk mengatasi permasalahan pembelajaran jarak jauh di pandemi covid-19. Jurnal Guru Kita, 4(3), 51-58. https://jurnal.unimed.ac.id/2012/index.php/jgkp/article/download/19472/13983 